\title{
Pengaruh Tingkat Kemiskinan dan Jumlah Penduduk Terhadap Indeks Pembangunan Manusia (IPM) Kabupaten Batang Hari 2011 -2019
}

\author{
Jasasila \\ STIE Graha Karya Muara Bulian \\ Correspondence email: jasasila@yahoo.co.id
}

\begin{abstract}
Human Development Index is used to measure how much impact arises from efforts to increase the ability of basic human capital. Human Development is a component of development through empowerment of the population that focuses on increasing the human base, judging from the population of Batang Hari Regency which is fluctuating and has the potential for human resources ready to be empowered. The implementation of regional autonomy gives flexibility to the Regional Government of Batang Hari Regency to carry out regional development more independently. Besides that what needs to be considered is the growth of the poor population, in Batanghari District the development of the poor population has also fluctuated, where in 2019 there was a decrease of $26.53 \%$ from the previous year. To measure poverty, BPS uses the concept of ability to meet basic needs approach. This is done in Batang Hari Regency, using data from 2011 - 2019. The type of data used in this study is Time Series data, which is the type of data consisting of variables collected according to the order of time within a certain timeframe, while the analytical methods used in This research is a quantitative method. Quantitative analysis is used to determine the Effect of Poverty Rate and Population Number on the human development index (HDI) in Batang Hari District 2011-2019. To analyze the influence of data analysis, this is done by using multiple linear regression models using Eviews program version 9.0. poverty level and Population simultaneously or together have a very significant effect on the Human Development Index in Batang Hari District 2011-2019. In this study the R2 value is 0.975311 which means a set of dependent variables (Poverty Rate and Population Number) in the model can explain the Independent variable by $97.53 \%$. While the rest is explained by other variables outside the model that are not examined. Human Development Index (HDI) of Batang Hari 2011-2019 is 32.58 assuming other variables (Poverty Rate and Population Growth Rate are fixed or 0) From the equation it is known that poverty variable shows a coefficient of 0.03 meaning that if there is an increase in poverty level of 1 unit it will increase the HDI by $0.03 \%$ with the assumption that the Population Variable is 0 . Whereas for the Total Population from the data processing, the result is 0.00013, meaning that every 1 person increase will increase the Human Development Index (HDI) by $0.00013 \%$.
\end{abstract}

Keywords: Human Development Index, Poverty, Population Number

\section{Pendahuluan}

Salah satu faktor dari pembangunan adalah kualitas Sumber Daya Manusia (SDM), Pemerintah sebagai pelaksana pembangunan tentunya membutuhkan modal manusia yang berkualitas sebagai modal dasar pembangunan. Untuk menghasilkan manusia yang berkualitas diperlukan upaya-upaya untuk meningkatkan kualitas SDMnya. Adapun kualitas manusia dapat diukur melalui Indeks Pembangunan Manusia. Indeks pembangunan manusia (IPM) atau Human Development Index ialah suatu metode pengukuran perbandingan dari harapan hidup, melek huruf, pendidikan dan standar hidup untuk semua negara seluruh dunia. IPM digunakan untuk dapat mengklasifikasikan apakah sebuah negara ialah negara maju, negara berkembang atau negara terbelakang dan juga untuk mengukur pengaruh dari kebijaksanaan ekonomi terhadap kualitas hidup. (diposting oleh samhis setiawan - 25-03-2020). Indeks Pembangunan Manusia digunakan untuk mengukur seberapa besar dampak yang ditimbulkan dari upaya peningkatan kemampuan modal dasar manusia.Pembangunan Manusia merupakan komponen pembangunan melalui pemberdayaan penduduk yang menitikberatkan pada peningkatan dasar manusia. Pembangunan yang dihitung menggunakan ukuran besar kecilnya angka pendidikan, kesehatan dan daya beli. Semakin tinggi angka yang diperoleh maka semakin tercapai tujuan dari pembangunan. Pembangunan merupakan sebuah proses untuk melakukan perubahan kearah yang lebih baik (Nur Baeti, 2013). Dalam menghasilkan SDM yang berkualitas diperlukan orangorang yang mampu berkompentensi. Menurut Adam Smith Inti dari proses pertumbuhan ekonomi dibagi menjadi dua aspek utama yaitu pertumbuhan output total dan pertumbuhan penduduk. Mengenai peranan penduduk dalam pembangunan ekonomi, Smith berpendapat bahwa perkembangan penduduk akan mendorong pembangunan ekonomi. Penduduk yang bertambah akan memperluas pasar, maka akan meningkatkan spesialisasi dalam perekonomian tersebut.

Perkembangan spesialisasi dan pembagian kerja akan mempercepat proses pembangunan ekonomi karena adanya spesialisasi akan meningkatkan produktivitas tenaga kerja dan mendorong perkembangan teknologi (Sadono Sukirno, 2010). Dilihat dari Jumlah Penduduk Kabupaten Batang Hari yang berfluktatif dan memiliki potensi sumber daya manusia yang siap untuk diberdayakan. Pelaksanaan otonomi daerah memberikan keleluasaan kepada Pemerintah Daerah Kabupaten Batang Hari untuk melaksanakan pembangunan daerah secara lebih mandiri. Disamping itu yang perlu diperhatikan adalah pertumbuhan penduduk miskin, di Kabupaten Batanghari perkembangan penduduk miskin juga mengalami fluktuatif dimana pada tahun 2019 
terjadi penurunan sebesar $26,53 \%$ dari tahun sebelumnya. Untuk mengukur kemiskinan, BPS menggunakan konsep kemampuan memenuhi kebutuhan dasar (basic needs approach). Dengan pendekatan ini, kemiskinan dipandang sebagai ketidakmampuan dari sisi ekonomi untuk memenuhi kebutuhan dasar makanan dan bukan makanan yang diukur dari sisi pengeluaran. Jadi Penduduk Miskin adalah penduduk yang memiliki ratarata pengeluaran perkapita perbulan dibawah garis kemiskinan. Kemiskinan dapat menjadikan efek yang cukup serius bagi pembangunan manusia karena masalah kemiskinan merupakan sebuah masalah yang kompleks yang sebenarnya bermula dari kemampuan daya beli masyarakat yang tidak mampu untuk mencukupi kebutuhan pokok sehingga kebutuhan yang lain seperti pendidikan dan kesehatan terabaikan. Hal tersebut menjadikan sekat pembangunan manusia diantara keduanya pun menjadi besar dan pada akhirnya target capaian IPM yang ditentukan oleh pemerintah menjadi tidak terealisasikan dengan baik.

Peran pemerintah dalam kebijakan pelaksanaan otonomi daerah dan desentralisasi fiskal didasarkan pada pertimbangan bahwa daerahlah yang lebih mengetahui kebutuhan dan standar pelayanan bagi masyarakat di daerahnya, sehingga pemberian otonomi daerah diharapkan dapat memacu peningkatan kesejahteraan masyarakat di daerah melalui peningkatan pertumbuhan ekonomi. Pertumbuhan ekonomi merupakan salah satu indikator ekonomi yang umum digunakan dalam menetukan keberhasilan pembangunan, pertumbuhan ekonomi digunakan atas perkembangan atau kemajuan perekonomian dari suatu negara atau wilayah karena berkaitan erat dengan aktivitas kegiatan ekonomi masyarakat khusunya dalam hal peningkatan produksi barang dan jasa .peningkatan tersebut kemudian diharapkan dapat memberikan trickle down efect yang mampu meningkatkan kesejahteraan masyarakat. Dari latar belakang diatas maka penulis tertarik untuk melakukan penelitian dengan rumusan masalah Bagaimana Pengaruh Tingkat Kemiskinan dan Jumlah Penduduk Terhadap Indeks Pembangunan Manusia Di Kabupaten Batang Hari 2011-2019, sedangkan tujuan penelitiannya adalah Untuk Mengetahui Pengaruh Tingkat Kemiskinan dan Jumlah Penduduk Terhadap Indeks Pembangunan Manusia Dikabupaten Batang Hari 2011-2019

\section{Metode}

Penelitian ini dilakukan di Kabupaten Batang Hari, dengan menggunakan data dari tahun 2011 - 2019. Jenis data yag digunakan dalam penelitian ini adalah data Time Series yakni jenis data yang terdiri atas variabel-variabel yang dikumpulkan menurut urutan waktu dalam suatu rentang waktu tertentu. Jika waktu dipandang bersifat diskrit (waktu dapat dimodelkan bersifat kontinu), frekuensi pengumpulan selalu sama (equidistant). Dalam kasus diskrit, frekuensi dapat berupa misalnya detik, menit, jam, hari, minggu, bulan atau tahun dan lain-lain (Dedi, 2011:1). Sumber data yang digunakan adalah data sekunder berasal dari Badan Pusat Statistik Provinsi Jambi dan Kabupaten Batang Hari yang diambil secara daring, meliputi data tingkat Kemiskinan, Jumlah Pendudukdan Indeks Pembangunan Manusia (IPM) Kabupaten Batang Hari 2011-2019. Sedangkan metode analisa yang digunakan dalam penelitian ini adalah metode kuantitatif. Analisis kuantitatif digunakan untuk mengetahui Pengaruh Tingkat Kemiskinan dan Jumlah Pendudukterhadap indeks pembangunan manusia (IPM) di Kabupaten Batang Hari 2011-2019. Untuk menganalisa pengaruh terhadap analisa data ini dilakukan dengan menggunakan model regresi linear berganda dengan menggunakan fasilitas program Eviews versi 9.0.

Dalam model atau persamaan tersebut pengaruh tingkat kemiskinan dan Jumlah Pendudukterhadap IPM dapat digambarkan dalam suatu bentuk fungsi sebagai berikut : $\mathrm{Y}=\mathrm{f}\left(\mathrm{X}_{1}, \mathrm{X}_{2}, \mathrm{X}_{3}\right)$ dimana :

$\mathrm{Y}=$ Indeks Pembangunan Manusia (IPM); $\mathrm{X}_{1}=$ Tingkat Kemiskinan; dan $\mathrm{X}_{2}=$ Jumlah Penduduk Selanjutnya model diatas akan dimasukkan ke dalam persamaan regresi linear berganda (Hasan, 2015) :

$\mathrm{Y}=\square_{\square} \square \square \square \square \square \mathrm{X}_{1}+\square_{\square} \mathrm{X}_{2}+\square$

dimana: $\mathrm{Y}=$ Indeks Pembangunan Manusia (IPM) (\%); $\mathrm{X}_{1}=$ Tingkat Kemiskinan $(\%) ; \mathrm{X}_{2}=$ Jumlah Penduduk (\%); $\square_{\square \square}=$ Konstanta; $\square_{\square} \square_{\square \square}=$ Koofesien Regresi; $\square=$ Residual

Hasil

Hasil analisis data berguna untuk melihat pengaruh antara variabel tingkat kemiskinan pertumbuhan ekonomi dan Jumlah Pendudukterhadap variabel IPM. Hasil analisis menggunakan regresi linear berganda diperoleh dengan menggunakan program Eviews 9.0. dengan hasil sebagai berikut :

\section{Tabel 1}

Hasil Penelitian

\begin{tabular}{|l|r|r|r|r|}
\hline \multicolumn{1}{|c|}{ Variable } & Coefficient & Std. Error & t-Statistic & Prob. \\
\hline C & 32.58221 & 2.333002 & 13.96578 & 0.0000 \\
\hline MISKIN & 0.029651 & 0.069104 & 0.429078 & 0.6828 \\
\hline JPDK & 0.000133 & $1.20 \mathrm{E}-05$ & 11.04474 & 0.0000 \\
\hline R-squared & 0.975311 & Mean dependent var & & 68.09778 \\
\hline Adjusted R-squared & 0.967081 & S.D. dependent var & 1.138747 \\
\hline
\end{tabular}


Jasasila, Pengaruh Tingkat Kemiskinan dan Jumlah Penduduk Terhadap Indeks Pembangunan Manusia (IPM) Kabupaten Batang Hari $2011-2019$

\begin{tabular}{|l|r|l|r|}
\hline S.E. of regression & 0.206608 & Akaike info criterion & -0.054781 \\
\hline Sum squared resid & 0.256122 & Schwarz criterion & 0.010960 \\
\hline Log likelihood & 3.246517 & Hannan-Quinn criter. & -0.196651 \\
\hline F-statistic & 118.5118 & Durbin-Watson stat & 2.319522 \\
\hline Prob(F-statistic) & 0.000015 & & \\
\hline
\end{tabular}

Sumber: data olahan

Hasil pengolahan diatas dapat dijelaskan :

a. Uji Simultan (uji F)

Dari hasil pengolahan data dengan melakukan uji simultan atau (uji F) maka secara simultan variabel tingkat kemiskinan dan Jumlah Penduduk terhadap variabel IPM. Dengan menggunakan tingkat signifikan 5\%. Hasil perhitungan Uji $F$ yang diperoleh bahwa tingkat kemiskinan dan Jumlah Penduduk secara bersama-sama mampu menjelaskan IPM di Kabupaten Batang Hari. Hal ini dijelaskan dengan nilai $\mathrm{F}_{\text {statistik }}<0,05$. Dimana nilai Prob (Fstatistik) sebesar 0.000015 sehingga tingkat kemiskinan dan Jumlah Penduduk secara simultan atau bersama - sama berpengaruh sangat signifikan terhadap Indeks Pembangunan Manusia di Kabupaten Batang Hari 2011-2019

b. Koofesien Determinasi $\left(\mathrm{R}^{2}\right)$

Nilai koefisien determinasi berganda dalam eviews sama seperti halnya dengan aplikasi lainnya, yaitu diberi label R-Squared. Dalam penelitian ini nilai $\mathrm{R}^{2}$ sebesar 0.975311 yang berarti sekumpulan variabel dependent ( Tingkat Kemiskinan dan Jumlah Penduduk) di dalam model dapat menjelaskan variabel Indenpendent sebesar 97,53\%. Sedangkan sisanya dijelaskan oleh variabel lain di luar model yang tidak diteliti.

c. Uji Parsial (Uji t)

Berdasarkan dari analisis regresi diperoleh data mengenai perhitungan masing-masing variabel Tingkat Kemiskinan, Pertumbuhan Ekonomi dan Jumlah Penduduk terhadap variabel Indeks Pembangunan Manusia di Kabupaten Batang Hari 2011-2019, dimana :

1) Tingkat Kemiskinan

Dari hasil pengolahan data yang ditampilkan melalui aplikasi Eviews 9.0 diperoleh nilai Prob ( $t$-value) untuk tingkat kemiskinan adalah 0.6828 , yang artinya nilai Prob ( $t$-value) lebih besar dari 0,05 atau 0.6828>0,05 menunjukkan bahwa secara parsial atau sendiri-sendiri tingkat kemiskinan mempunyai pengaruh yang tidak siginifikan terhadap Indeks Pembangunan Manusia di Kabupaten Batang Hari 2011-2019.

2) Jumlah Penduduk

Dari hasil pengolahan data yang ditampilkan melalui aplikasi Eviews diperoleh nilai Prob ( $t$ value) untuk Jumlah Penduduk adalah 0.0000, yang artinya nilai Prob ( $t$-value) lebih kecil dari 0,05 atau $0.0000<0,05$ menunjukkan bahwa secara parsial atau sendiri-sendiri Jumlah Penduduk mempunyai pengaruh yang siginifikan terhadap Indeks Pembangunan Manusia di Kabupaten Batang Hari 2011-2019.

d. Interprestasi hasil persamaan linear berganda Dari pengolahan data melaui aplikasi Eviews didapat persamaan regresi liner berganda sebagai berikut : $\mathrm{IPM} \quad$ = $32.5822069488+$ $0.0296509261692 *$ MISKIN $0.000132996076638 *$ LPPDK Atau dapat dirumuskan dari model menjadi persamaan : $\mathrm{Y}=32.58+0.03\left(\mathrm{X}_{1}\right)+0.00013\left(\mathrm{X}_{2}\right)$

Dengan penjelasan :

1) Indek Pembangunan Manusia (IPM) Kabupaten Batang Hari 2011-2019 adalah 32.58 dengan asumsi variabel lain ( Tingkat Kemiskinan dan Laju Petumbuhan Penduduk adalah tetap atau 0)

2) Berdasarkan hasil penelitian ini diperoleh bahwa Kemiskinan berpengaruh walaupun tidak signifikan terhadap Indeks Pembangunan Manusia di Kabupaten Batang Hari selama 2011-2019. Dari persamaan diketahui variabel kemiskinan menunjukkan koefisien sebesar 0.03 artinya jika terjadi kenaikan tingkat kemiskinan sebesar 1 satuan maka akan manaikkan IPM sebesar $0,03 \%$ dengan asusmsi Variabel Jumlah Penduduk adalah 0 , berarti setiap peningkatan Kemiskinan akan meningkatkan persentase IPM di Kabupaten Batang Hari. Hasil penelitian ini tidak sesuai dengan teori kemiskinan absolut dimana sejumlah penduduk yang tidak mampu mendapatkan sumber daya yang cukup untuk memenuhi kebutuhan dasar, penduduk hidup dibawah pendapatan rill minimum atau dapat dikatakan hidup dibawah kemiskinan Internasional. (Todaro dan Smith, 2006). Jika garis kemiskinan semakin meningkat dan manusia tidak mampu memenuhi kebutuhan dasar mereka maka akan terciptanya lingkaran setan dimana akan terlihat dari rendahnya pendapatan nyata sehingga akan mengakibatkan permintaan menjadi rendah sehingga investasi juga rendah dan dapat mengurangi produktivitas. Selain itu, lingkaran setan juga menyangkut keterbelakangan manusia dan sumberdaya alam, dimana perkembangan sumberdaya alam itu tergantung pada kemampuan produktivitas manusianya. 
3) Sedangkan untuk Jumlah Penduduk dari pengolahan data didapat hasil 0.00013 artinya setiap kenaikan 1 orang Penduduk akan Meningkatan Indeks Pembangunan Manusia (IPM) sebesar $0.00013 \%$. Dengan asumsi Variabel Tingkat Kemiskinan adalah 0. Hal ini sesuai dengan penelitian (Melliana \& Zain, 2013), bahwa dalam proses produksi perusahaan pasti akan memerlukan tenaga kerja untuk memproduksi sebuah output. Ketika perusahaan ingin meningkatkan output produksinya maka akan menambah tenaga kerja untuk produksinya sehingga akan banyak membutuhkan tenaga kerja. Dengan demikian maka pertumbuhan penduduk akan dapat meningkatkan kualitas sumber daya manusia jika itu dapat direalisasikan dengan baik oleh pemerintah. Hal tersebut dikarenakan ketika jumlah penduduk meningkat maka kebutuhan masyarakat akan meningkat, konsumsi masyarakat akan meningkat dan lapangan kerja akan meningkat pula. Berpengaruh terhadap IPM juga dikarenakan adanya migrasi dari suatu daerah ke daerah lain yang dimana seseorang tersebut telah berada pada angkatan kerja dan sudah matang untuk bekerja sehingga akan meningkatkan kualitas sumber daya manusia yang ada pada daerah tersebut. Meningkatnya arus migrasi akan berdampak pada bagi pembangunan daerah atau nasional serta bagi penduduk dan negara. Dengan adanya migrasi maka suatu pembangunan akan berkembang karena kontribusi dari para pendatang serta keahliannya yang dibawa sehingga akan meningkatkan pendapatan.

\section{Simpulan}

1. Hasil perhitungan Uji $\mathrm{F}$ yang diperoleh bahwa tingkat kemiskinan dan Jumlah Penduduk secara bersama-sama mampu menjelaskan IPM di Kabupaten Batang Hari. Hal ini dijelaskan dengan nilai $F_{\text {statistik }}<0,05$. Dimana nilai Prob (F-statistik) sebesar 0.000015 sehingga tingkat kemiskinan dan Jumlah Penduduk secara simultan atau bersama sama berpengaruh sangat signifikan terhadap Indeks Pembangunan Manusia di Kabupaten Batang Hari 2011-2019

2. Dalam penelitian ini nilai $\mathrm{R}^{2}$ sebesar 0.975311 yang berarti sekumpulan variabel dependent ( Tingkat Kemiskinan dan Jumlah Penduduk) di dalam model dapat menjelaskan variabel Indenpendent sebesar $97,53 \%$. Sedangkan sisanya dijelaskan oleh variabel lain di luar model yang tidak diteliti.

3. Indek Pembangunan Manusia (IPM) Kabupaten Batang Hari 2011-2019 adalah 32.58 dengan asumsi variabel lain ( Tingkat Kemiskinan dan Laju Petumbuhan Penduduk adalah tetap atau 0)

4. Dari persamaan diketahui variabel kemiskinan menunjukkan koefisien sebesar 0.03 artinya jika terjadi kenaikan tingkat kemiskinan sebesar 1 satuan maka akan manaikkan IPM sebesar 0,03\% dengan asusmsi Variabel Jumlah Penduduk adalah 0

5. Sedangkan untuk Jumlah Penduduk dari pengolahan data didapat hasil 0.00013 artinya setiap kenaikan 1 orang Penduduk akan Meningkatan Indeks Pembangunan Manusia (IPM) sebesar $0.00013 \%$.

\section{Daftar Pustaka}

Arsyad, Lincoln. 2010. Ekonomi Pembangunan. Yogyakarta: Unit Penerbit dan Percetakan STIM YKPN Yogyakarta.

Badan Pusat Statistik: Jambi Dalam Angka. 2012-2020. Jambi: Badan Pusat Statistik Jambi.

Baeti, Nur.2013. Pengaruh Pengangguran, Pertumbuhan Ekonomi, dan Pengeluaran Pemerintah terhadap Pembangunan Manusia Kabupaten/Kota di Provinsi Jawa Tengah tahun 2007-2011. Jurnal Ekonomi dan Studi Pembangunan. Vol. 2 (3) (2013).

Jasasila, Dampak Ekonomi dan Evaluasi Belanja Daerah terhadap Pembangunan di Kabupaten Batang Hari (studi kasus : Sektor Pendidikan). Jurnal Ilmiah Universitas Batnghari Jambi 15 (2) 68-72. 2017

Boediono, 1999, Teori Pertumbuhan Ekonomi, BPFE UGM Yogyakarta.

Mankiw, N. Gregory. 2012. Makroekonomi. Jakarta: Erlangga.

Maryani, Tri. 2011.Analisis Indeks Pembangunan Manusia Di Provinsi Jawa Tengah. Skripsi.

Irsad dan Kasyful, (2008). 'Pembangunan Manusia di Indonesia dan Faktor-Faktor- faktor yang mempengaruhinya:

Mirza,Sulistio,Deni $2012 . \quad$ "Pengaruh kemiskinan,Pertumbuhan Ekonomi,dan Belanja Modal Terhadap Indeks Pembangunan Manusia di Jawa Tengah Tahun 2006-2009.

Lanjow,2007. Pengaruh Indikator Komposit Indeks Pembangunan Manusia terhadap Penurunan Jumlah Penduduk Miskin di Sumatera Utara. Skripsi. Medan: Fakultas Ekonomi Universitas Sumatera Utara.

Nanga, Muana. 2005.Makroekomoni. Jakarta : Erlangga

Patta, Devianti(2011). Analisis Faktor-faktor yang Mempengaruhi Indeks Pembangunan Manusia di Sulawesi Selatan Periode 2001-2010. Skripsi. Makasar: Fakultas Ekonomi Universitas Hasanudin.

Riski, dkk 2015. Pemodelan Indeks Pembangunan Manusia di Provinsi Jawa Tengah tahun 2008- 
Jasasila, Pengaruh Tingkat Kemiskinan dan Jumlah Penduduk Terhadap Indeks Pembangunan Manusia (IPM) Kabupaten Batang Hari 2011 -2019

2013 dengan Menggunakan Regresi Data Panel. Jurnal Gaussian: Vol. 4 (2) (2015).

Samuelson A, Paul . 2004. Ilmu Makro Ekonomi. Jakarta: PT. Media Global Edukasi.

Todaro, P Michael. 2011. Pembangunan Ekonomi. Jakarta: Erlangga.

Winarno, WingWahyu. 2009. Analisis Ekonometrika dan Statistika dengan Eviews. Yogyakarta: 